\title{
PENGARUH PENERAPAN MEDIA GAMBAR TERHADAP HASIL BELAJAR SISWA PADA MATA PELAJARAN EKONOMI DI SMA N 1 ABAB TAHUN PELAJARAN 2018/2019
}

\author{
Oleh: Dwi Septia Sari ${ }^{1}$, Yasir Arafat ${ }^{2}$, Hendri Gunawan ${ }^{3}$ \\ (UNIVERSITAS PGRI PALEMBANG)
}

rusfah12@gmail.com $^{1}$, jayasampurna85@gmail.com ${ }^{3}$

\begin{abstract}
Abstrak-Tujuan penelitian ini yaitu untuk mengetahui adakah Pengaruh Penerapan Media Gambar Terhadap Hasil Belajar Siswa Pada Mata Pelajaran Ekonomi Di SMA N 1 Abab Tahun Pelajaran 2018/2019. Metode yang digunakan adalah penelitian eksperimen semu (kuasi eksperimen). Hasil penelitian berdasarkan hasil hipotesis yang dilakukan menggunakan uji $t$ adapun rumus regresi ynga digunakan adalah regresi linier sederhana dummy variabel, terdapat pengaruh penerapan media gambar terhadap hasil belajar siswa pada mata pelajaran ekonomi di SMA Negeri 1 Abab tahun pelajaran 2018/2019. Hal ini terlihat dari hasil hipotesis yang diperoleh $t_{\text {hitung }} 4,766>t_{\text {tabel }} 1,996$, maka tolak Ho diterima Ha berarti dapat disimpulkan terdapat pengaruh media gambar terhadap hasil belajar siswa di SMA Negeri 1 Abab Tahun Pelajaran 2018/2019, dengan besar pengaruh 25,88\% pada kriteria rendah, sedangkan sisanya 74,12\% dipengaruhi faktor lain.
\end{abstract}

Kata Kunci : Penerapan Media Gambar, Hasil Belajar Ekonomi

Abstract-The purpose of this study is to find out whether there is an effect of the application of image media on student learning outcomes in economic subjects at Abab N 1 High School 2018/2019 Academic Year. The method used is quasiexperimental research (quasi-experiment).The results of the study are based on the results of the hypothesis carried out using the $t$ test while the regression formula that is used is a simple linear regression dummy variable, there is the influence of the application of image media on student learning outcomes on economic subjects in Abab 1 Public High School 2018/2019. This can be seen from the results of the hypothesis that obtained tcount 4.766>t table 1.996, then reject Ho accepted Ha means it can be concluded that there is influence of media images on student learning outcomes in Abab 1 Public High School 2018/2019 Academic Year, with the influence of $25.88 \%$ on the criteria low, while the remaining $74.12 \%$ is influenced by other factors.

Keywords : Application of Image Media, Economic Learning Outcomes.

\section{PENDAHULUAN}

Pembelajaran merupakan suatu proses pendidikan secara keseluruhan dengan pendidik sebagai pembimbing dalam memberikan pembelajaran dan motivasi kepada siswa. Seorang guru dalam kegiatan belajar mengajar tidak hanya dituntut 
untuk memiliki kemampuan dalam pengalaman teoritis tapi juga harus memiliki kemampuan praktis. Kedua hal ini sangat penting karena seorang guru dalam pembelajaran bukan sekedar menyampaikan materi semata tetapi juga berupaya agar mata pelajaran yang sedang disampaikan menjadi kegiatan pembelajaran yang menyenangkan dan mudah dipahami bagi siswa. Maka dalam hal ini pemerintah mengharapkan dengan adanya pendidikan masyarakat atau peserta didik dapat mempersiapkan dirinya untuk menjadi manusia yang memiliki akhlak mulia, memiliki kemampuan,pengetahuan, dan keterampilan, serta dapat melaksanakan tugas dan tanggung jawab baik secara pribadi maupun dalam hidup bermasyarakat. Sesuai dengan tujuan pendidikan yang telah dijelaskan, siswa dituntut untuk dapat berinteraksi dengan lingkungannya, khususnya lingkungan sekolah atau lingkungan belajardengan bimbingan dan panduan dari padar guru melalui proses belajar mengajar.

Media pembelajaran terdapat banyak jenis dan macamnya. Ada yang sudah tersedia dilingkungan untuk langsung dimanfaatkan ada yang sengaja dirancang. Berbagai sudut pandang mendefinisikan tentang media salah satunya yaitu, Berbagai bentuk media dapat digunakan untuk meningkatkan pengalaman belajar ke arah yang lebih konkret termasuk media gambar karena dengan media gambar siswa lebih termotivasi dan lebih mengesankan, sehingga tahan lama pada ingatan siswa dan tentunya dapat memberikan hasil belajar terbaik untuk siswa.

Menurut Daryanto (2010:108) gambar fotografi merupakan salah satu media pengajaran yang amat dikenal di dalam setiap kegiatan pengajaran dan dipergunakan baik untuk tujuan pengajaran individual, kelompok kecil maupun untuk kelompok besar yang dibantu dengan proyektor opek atau opaque projektor.

Dalam proses pembelajaran di sekolah peranan guru dan siswa sangatlah penting maka istilah pembelajaran berhubungan erat dengan pengertian belajar dan mengajar yang terjadi bersama-sama. Menurut Parwati,dkk (2018:107) Belajar adalah suatu proses yang kompleks yang terjadi pada semua orang dan berlangsung seumur hidup, sejak masih bayi sampai akhir hayat, dan dapat terjadi tanpa guru atau tanpa kegiatan mengajar dan pembelajaran formal lainnya. Maka dari itu untuk menunjang hasil belajar yang tinggi sebagai guru kita harus lebih kreatif dan inovatif dalam kegiatan pembelajaran di dalam kelas khususnya dalam hal penggunaan media pembelajaran. Dengan menggunakan media pembelajaran yang tepat dan bervariasi dapat mengatasi sikap 
pasif siswa dan hasil belajar siswa juga akan meningkat. Dengan demikian hasil belajar siswa akan lebih cepat tertanan secara maksimal dalam diri siswa, apabila pesertaa didik memperoleh pembelajaran yang menyenangkan dengan menggunakan media pembelajaran yang kreatif dan inovatif.

Menurut Parwati (2018:50) Hasil belajar adalah apa yang di peroleh setelah melakukan belajar. Menurut Suprijono (2015:5) hasil belajar adalah 'pola-pola perbuatan, nilai-nilai, pengertian-pengertian, sikap-sikap, apresiasi dan keterampilan. Menurut Jihad dan Haris (2013:14) hasil merupakan pencapaian bentuk perubahan perilaku yang cenderung menetap dari ranah kognitif, afektif dan psikomotrik dari proses belajar yang dilakukan dalam waktu tertentu. Belajar sangat erat hubungannya dengan hasil belajar. Karena hasil belajar yang maksimal dapat dicapai oleh peserta didik, maka saat ini diperlukan banyak dikembangkan media pembelajaran yang berguna dan bertujuan untuk mendorong siswa dalam meningkatkan keaktifan siswa dalam proses pembelajaran. Dimana dalam hal ini peneliti menerapkan media gambar dalam proses pembelajaran untuk meningkatkan hasil belajar siswa khususnya pada mata pelajaran ekonomi. kurang termotivasi dalam kegiatan pembelajaran siswa cenderung masih rendah dikarenakan tidak terlibatkan siswa secara aktif dalam proses pembelajaran sehingga siswa kurang interaktif dan kurangnya variasi belajar menggunakan media dalam penyampaian materi pembelajaran sehingga kegiatan pembelajaran lebih monoton dan siswa kurang termotivasi dalam mengikuti proses pembelajaran.

Menurut Sadiman, dkk (2014:7) Media adalah bentukbentuk komunikasi baik tercetak maupun audio visual serta peralatannya dan segala sesuatu yang digunakan untuk menyalurkan pesan dari pengirim ke penerima sehingga dapat merangsang pikiran,perasaan, perhatian dan minat serta perhatian siswa sedmikian rupa sehinngga proses belajar terjadi. Daryanto (2010:5) mengatakan bahwa kata media merupakan bentuk jamak dari kata medium. Medium dapat didefinisikan sebagai perantara atau pengantar terjadinya komunikasi dari pengirim menuju penerima. Jadi dapat disimpulkan bahwa media merupakan alat atau bahan yang digunakan agar siswa lebih termotivasi dan inovatif dalam kegiatan pembelajaran.

Berdasarkan Observasi awal yang telah peneliti lakukan di SMA Negeri 1 Abab, bahwa media pembelajaran yang dilakukan menggunakan cara pembelajaran yang konvensional penggunaan cara pembelajaran konvensional telah berjalan dengan baik akan tetapi 
belum mendapatkan hasil yang maksimal,hal ini dapat dilihat dari ketuntnasan $65 \%$ dan yang sudah tuntas $35 \%$ dari KKM 75 yang telah di tentukan oleh sekolah.

Selain faktor media pembelajaran yang menentukan ketuntasan siswa juga di pengaruhi faktor-faktor lain. Berdasarkan uraian maka peneliti tertarik untuk melakukan penelitian skripsi yang berjudul "Pengaruh Penerapan Media Gambar Terhadap Hasil Belajar Siswa Pada Mata Pelajaran Ekonomi di SMA N 1 Abab Tahun Pelajaran 2018/201

\section{Kajian Terdahulu Yang Relevan}

Berikut ini penelitian-penelitian terdahulu yang ada hubungannya dengan penelitian sebelumnya ini dapat dijadikan pembanding, yaitu :

1. Penelitian Desti Pratiwi 2012132055 Fakultas Keguruan dan Ilmu Pendidikan (FKIP) Universitas PGRI Palembang telah melakukan penelitian dengan judul "Pengaruh Penggunaan Media Gambar Terhadap Hasil Belajar Siswa Pada Mata Pelajaran IPS Terpadu (Ekonomi ) Di SMP PGRI Pagaralam Tahun Pelajaran 2016/2017'. Metode yang digunakan dalam penelitian ini adalah metode eksperimen. Hasil penelitian menggunakan media gambar di dapat nilai rata-rata hasil belajar kelas eksperimen 74,67 sedangkan nilai rata-rata hasil belajar kelas kontrol 66,61 dan dari pengujian hipotesis diperoleh $\mathrm{t}_{\text {hitung }} 3,10>\mathrm{t}_{\text {tabel }} 1,671$ maka $\mathrm{H}_{\mathrm{o}}$ ditolak dan $\mathrm{H}_{\mathrm{a}}$ diterima. Maka hipotesis yang diperoleh, ada pengaruh penggunaan media gambar terhdapa hasil belajar siswa pada mata pelajaran IPS Terpadu (Ekonomi) di SMP PGRI kategori rendah dan sisanya dipengaruhi oleh faktor lain.

2. Penelitian Ria Hesty Umri 2013132015 Fakultas Keguruan Dan Ilmu Pendidikan (FKIP) Universitas PGRI Palembang telah melakukan penelitian dengan judul "Pengaruh Penerapan Media Flash Card Terhadap Hasil Belajar Siswa Pada Mata Pelajaran Ekonomi Di SMA Yayasan Bhakti Prabumulih 2017/2018”. Metode yang digunakan dalam penelitian ini adalah metode eksperimen. Hasil pengujian normalitas data kelas eksperimen yaitu $\mathrm{x}^{2} \mathrm{t}_{\text {hitung }} 8,914<$ $\mathrm{x}^{2} \quad \mathrm{t}_{\text {tabel }} 11,070$ dan pada kelas kontrol yaitu $\mathrm{x}^{2} \mathrm{t}_{\text {hitung }} 6,141<\mathrm{x}^{2}$ $\mathrm{t}_{\text {tabel }} 11,070$ yang berarti data nilai siswa kelas eksperimen dan kelas kontrol berdistribusi normal. Hasil uji homogenitas data menunjukkan $F_{\text {hitung }}=1,149<$ $F_{\text {tabel }} \alpha 0,05=2,00$ maka hasil belajar siswa kelas eksperimen dan kelas kontrol dinyatakan homogen.Pada pengujian hipotesis berdasarkan hasil persamaan regresi yaitu $\mathrm{Y}=71,19$ $+10,4 \mathrm{X}$ diperoleh hasil dengan 
menggunakan uji $\mathrm{t}$ yaitu $\mathrm{t}_{\text {hitung }}=$ $3,56>t_{\text {tabel }}=1,67$ dengan demikian $\mathrm{H}_{\mathrm{a}}$ diterima dan $\mathrm{H}_{\mathrm{o}}$ ditolak menunjukkan berarti ada pengaruh penerapan media flash card terhadap hasil belajar siswa pada mata pelajaran ekonomi di SMA Yayasan Bhakti Prabumulih.

3. Peneliti Dhaniar Harahap PGSD Univeritas Nahdlatul Ulama Sumatera Utara, Telah melakukan penelitian yang berjudul Penggunaan Media Gambar Untuk Meningkatkan Hasil Belajar IPS Siswa Pada Tahun 2016. Pada test hasil belajar I dari 37 orang siswa yang mengikuti test, terdapat 18 orang siswa atau $48,64 \%$ yang tuntas belajar dan yang tidak tuntas belajar sebanyak 19 siswa atau 51,36\%. Pada hasil belajar siklus II, dari 37 siswa yang mengikuti test terdapat 35 siswa atau $94,60 \%$ yang tuntas belajar, dan ada 2 siswa atau $5,40 \%$.

\section{METODE PENELITIAN}

Penelitian ini dilakukan di SMA N 1 Abab yang berada di Penukal Abab kabupaten PALI. Adapun pelaksanaan penelitian ini akan dilakukan selama lebih kurang tiga minggu, yaitu dari pertengahan bulan April sampai berakhir waktu penelitian. Penelitian ini akan dilakukan di kelas X IPS 1 dan kelas X IPS 2 Pada Semester Genap Tahun Pelajaran 2018/2019.
Arikunto

(2013:203)

mengatakan bahwa metode penelitian adalah cara yang digunakan oleh peneliti dalam mengumpulkan data penelitiannya. Sugiono (2017:2) mengatakan bahwa metode penelitian adalah cara ilmiah untuk mendapatkan data dengan tujuan dan kegunaan tertentu. Menurut Basir dan Amrina (2017:30). Penelitian yang digunakan adalah penelitian eksperimen semu(kuasi eksperimen) eksperimen ini merupakan pengembaangan dari eksperimen sebenarnya dan eksperimen semu tidak dipilih secara random. Teknik pengumpulan data berupa tes, teknik dokumentasi, observasi.

\section{HASIL PENELITIAN DAN PEMBAHASAN}

\section{Hasil Penelitian Dikaitkan dengan Kajian Teori}

Berdasarkan hasil analisis tersebut, pengaruh hasil belajar tersebut dikarenakan dalam pelaksanaan proses pembelajaran pada kelas eksperimen menggunakan penerapan media gambar agar siswa aktif dalam proses pembelajaran. Dengan begitu siswa akan lebih memahami dan akan tertanam dalam ingatan yang pada akhirnya berdampak pada peningkatan siswa dalam penguasaan materi yang di berikan selama proses pembelajaran. Sedangkan dalam pelaksanaan proses pembelajaran di kelas kontrol dengan pembelajaran 
konvensional atau ceramah siswa pasif dalam proses pembelajaran yang dilakukan sehingga berdampak pada siswa yang akhirnya kurang penguasai dan memahami materi yang di ajarkan.

Hal tersebut dikarenakan pada media pembelajaran yaitu media gambar melibatkan siswa berperan aktif dalam proses pembelajaran. Penerapan media gambar dengan materi konsep manajemen dilakukan dengan cara pembelajaran media gambar yang digunakan berupa banner dan dijelaskan satu persatu setelah siswa memahami materi yang dijelaskan peneliti maka beberapa siswa diminta ke depan kelas untuk menjelaskan dan menarik kesimpulan dari materi yang sdh di jelaskan oleh peneliti. Penerapan media gambar siswa dapat lebih aktif dalam proses pembelajaran dan berpengaruh terhadap kesungguhan siswa dalam proses belajar mengajar. Hal ini terlihat dari rata-rata hasil belajar yang diperoleh siswa melalui tes.

Media merupakan alat atau bahan yang digunakan agar siswa lebih termotivasi dan inovatif dalam kegiatan pembelajaran. Sedangkan media gambar adalah media visual yang hanya bisa dilihat saja tetapi tidak mempunyai unsur audio atau suara merupakan media pembelajaran yang menekankan pada alat atau bahan yang digunakan berupa gambar dalam proses pembelajaran. Dalam pembelajaran khususnya pembelajaran ekonomi dengan materi konsep manajemen berdasarkan penelitian yang telah dilakukan media gambar memberikan tingkat keaktifan belajar siswa sehingga dapat meningkatkan hasi belajar siswa dalam kategori rendah.

Berdasarkan hasil distribusi belajar kelas eksperimen siswa yang memperoleh nilai 86-100 sebesar $12,12 \%$ "Baik Sekali”, dan yang memperoleh nilai dengan kriteria "Baik" 45,45 \%, dan dengan kriteria "Cukup" 42,42 \%, rata-rata hasil belajar siswa kelas eksperimen yaitu 75,4. Sedangkan distribusi hasil belajar kelas kontrol yaitu siswa yang memperoleh nilai 86-100 sebesar 8,82 \% “ Baik Sekali”, dan yang memperoleh nilai dengan kriteria "Baik" 41,17 \%, dan dengan kriteria "Cukup" 35,29 \% dan 14,70 $\%$. rata-rata hasil belajar siswa kelas kontrol yaitu 64,5. Maka thitung 4,766 $>t_{\text {tabel }} 1,996$, maka tolak Ho diterima Ha berarti terdapat pengaruh media gambar terhadap hasil belajar siswa di SMA Negeri 1 Abab Tahun Pelajaran 2018/2019, dengan besar pengaruh $25,88 \%$ pada kriteria rendah, sedangkan sisanya $74,12 \%$ dipengaruhi faktor lain. Sedang besar koefisien korelasi 50\% pada kriteria sedang.

\section{Hasil Penelitian Dikaitkan dengan Kajian Terdahulu yang Relevan}


Berdasarkan hasil penelitian,maka senada dengan pendapat Penelitian Desti Pratiwi 2012132055 Fakultas Keguruan dan Ilmu Pendidikan (FKIP) Universitas PGRI Palembang telah melakukan penelitian dengan judul "Pengaruh Penggunaan Media Gambar Terhadap Hasil Belajar Siswa Pada Mata Pelajaran IPS Terpadu (Ekonomi ) Di SMP PGRI Pagaralam Tahun Pelajaran 2016/2017'. Hasil pengujian hipotesis diperoleh $\mathrm{t}_{\text {hitung }} 3,10>\mathrm{t}_{\text {tabel }}$ 1,671 maka $\mathrm{H}_{\mathrm{o}}$ ditolak dan $\mathrm{H}_{\mathrm{a}}$ diterima.

Selain itu senada dengan penelitian penelitian Gunawan (2017) Universitas PGRI Palembang dengan judul "Implementasi Mata Kuliah Akuntansi Manajemen Sebagai Media Pembelajaran Keseharian Mahasiswa FKIP Akuntansi Universitas PGRI Palembang". Hasil penelitian bahwa implementasi mata kuliah akuntansi manajemen memiliki pengaruh yang positif dalam hal manajemen dan mengalokasikan keuangan mereka miliki untuk setiap bulannya khususnya pada mahasiswa semester 6 Prodi Pendidikan Akuntansi Universitas PGRI Palembang Tahun Pelajaran 2013/2014.

Selain itu sejalan senada dengan pendapat Penelitian Penelitian Ria Hesty Umri 2013132015 Fakultas Keguruan Dan Ilmu Pendidikan (FKIP) Universitas PGRI Palembang telah melakukan penelitian dengan judul "Pengaruh Penerapan Media Flash Card Terhadap Hasil Belajar Siswa Pada Mata Pelajaran Ekonomi Di SMA Yayasan Bhakti Prabumulih 2017/2018". Terbukti dari hasil pengujian hipotesis berdasarkan hasil persamaan regresi yaitu $\mathrm{Y}=$ $71,19+10,4 \mathrm{X}$ diperoleh hasil dengan menggunakan uji $\mathrm{t}$ yaitu $\mathrm{t}_{\text {hitung }}=3,56>\mathrm{t}_{\text {tabel }}=1,67$

Hasil analisis dalam penelitian ini menunjukkan bahwa terdapat pengaruh penerapan media gambar terhadap hasil belajar siswa pada mata pelajaran ekonomi di SMA Negeri 1 Abab tahun pelajaran 2018/2019. Hasil perhitungan hasil belajar siswa yang diperoleh dari nilai tes soal hasil belajar kelas eksperimen siswa yang memperoleh nilai 86-100 sebesar 12,12 \% Baik Sekali, yang memperoleh nilai dengan kriteria Baik 45,45 \%, dan dengan kriteria Cukup 42,42 \%, ratarata hasil belajar siswa kelas eksperimen yaitu 75,4. Sedangkan nilai tes soal hasil belajar kelas kontrol yaitu siswa yang memperoleh nilai 86-100 sebesar $8,82 \%$ Baik Sekali, dan yang memperoleh nilai dengan kriteria Baik 41,17\%, dan dengan kriteria Cukup 35,29 \% dan 14,70 \%. ratarata hasil belajar siswa kelas kontrol yaitu 64,5.

Peneliti Dhaniar Harahap PGSD Univeritas Nahdlatul Ulama Sumatera Utara, Telah melakukan penelitian yang berjudul Penggunaan 
Media Gambar Untuk Meningkatkan Hasil Belajar IPS Siswa Pada Tahun 2016. Pada test hasil belajar I dari 37 orang siswa yang mengikuti test, terdapat 18 orang siswa atau $48,64 \%$ yang tuntas belajar dan yang tidak tuntas belajar sebanyak 19 siswa atau $51,36 \%$. Pada hasil belajar siklus II, dari 37 siswa yang mengikuti test terdapat 35 siswa atau $94,60 \%$ yang tuntas belajar, dan ada 2 siswa atau $5,40 \%$

Penelitian menggunakan rumus Uji-t dengan kriteria pengujian : $t_{\text {hitung }} 4,766>t_{\text {tabel }} 1,996$, maka tolak Ho diterima Ha berarti dapat disimpulkan terdapat pengaruh penerapan media gambar terhadap hasil belajar siswa di SMA Negeri 1 Abab Tahun Pelajaran 2018/2019, dengan besar pengaruh $25,88 \%$ pada kriteria rendah, sedangkan sisanya $74,12 \%$ dipengaruhi faktor lain

Dalam pembelajaran khususnya pembelajaran ekonomi dengan materi konsep manajemen dengan menggunakan media pembelajaran yaitu media gambar dalam proses pembelajaran, karena berdasarkan penelitian yang telah dilakukan media gambar memberikan tingkat keaktifan dan motivasi siswa dalam pembelajaran sehingga dapat meningkatkan hasil belajar siswa dalam kategori rendah

\section{KESIMPULAN DAN SARAN Kesimpulan}

Berdasarkan hasil penelitian dan pembahasan mengenai pengaruh penerapan media gambar terhadap hasil belajar siswa pada mata pelajaran ekonomi di SMA Negeri 1 Abab tahun pelajaran 2018/2019 dapat disimpulkan sebagai berikut :

1. Berdasarkan analisis data teknik dokumentasi hasil belajar siswa pada mata pelajaran Ekonomi kelas eksperimen siswa yang memperoleh nilai 86-100 sebesar $12,12 \%$ Baik Sekali, yang memperoleh nilai dengan kriteria Baik 45,45 \% , dan dengan kriteria Cukup 42,42\%, rata-rata hasil belajar siswa kelas eksperimen yaitu 75,4. Sedangkan nilai tes soal hasil belajar kelas kontrol yaitu siswa yang memperoleh nilai 86-100 sebesar $8,82 \%$ Baik Sekali, dan yang memperoleh nilai dengan kriteria Baik 41,17 \% , dan dengan kriteria Cukup 35,29 \% dan 14,70 $\%$. rata-rata hasil belajar siswa kelas kontrol yaitu 64,5.

2. Berdasarkan hasil hipotesis yang dilakukan menggunakan uji $\mathrm{t}$ adapun rumus regresi ynga digunakan adalah regresi linier sederhana dummy variabel, terdapat pengaruh penerapan media gambar terhadap hasil belajar siswa pada mata pelajaran ekonomi di SMA Negeri 1 Abab tahun pelajaran 2018/2019. Hal ini terlihat dari hasil hipotesis yang diperoleh $t_{\text {hitung }} 4,766>t_{\text {tabel }}$ 1,996, maka tolak Ho diterima Ha berarti dapat disimpulkan ada pengaruh penerapan media 
gambar terhadap hasil belajar siswa di SMA Negeri 1 Abab Tahun Pelajaran 2018/2019, dengan besar pengaruh 25,88\% pada kriteria rendah, sedangkan sisanya $74,12 \%$ dipengaruhi faktor lain

\section{Saran}

Berdasarkan hasil penelitian ini, peneliti ingin memberikan saran sebagai berikut :

1. Bagi guru, khususnya guru mata pelajaran ekonomi dengan menggunakan media pembelajaran yaitu media gambar yaitu agar dapat dijadikan alternatif dalam keegiatan belajar mengajar diharapkan agar dapat meningkatkan keaktifan dan hasil belajar siswa selama kegiatan belajar mengajar.

2. Bagi sekolah, diharapkan hasil penelitian ini dapat dijadikan masukan pemikiran dalam meningkatkan kemampuan siswa dalam proses belajar mengajar dan kualitas dalam proses pembelajaran.

3. Bagi siswa, dengan menggunakan media pembelajaran yaitu media gambar dapat mencipatakan situasi belajar yang kondusif dan merangsang siswa untuk berperan aktif selama proses pembelajaran

\section{DAFTAR PUSTAKA}

Arikunto., Suharsimi. 2013. Prosedur Penelitian. Jakarta : Rineka Cipta
Astuti. Dwi. 2016. Buku Guru Ekonomi Untuk SMA/MA X Peminatan Ilmu-Ilmu Sosial. Surakarta : CV Mediatama

Basir. Djahir.,Amrina. Eka. Dian. 2017. Pengantar Metode Penelitian Pendidikan. Kampus UNSRI Palembang : UPT UNSRI Palembang dan Percetakan

Daryanto., 2010. Media Pembelajaran. Yogyakarta : Gava Media

Pratiwi. Desti. 2017. Pengaruh Penggunaan Media Gambar Terhadap Hasil Belajar Siswa Pada Mata Pelajaran IPS Terpadu (Ekonomi) Di SMP PGRI Pagaralam Tahun Pelajaran 2016/2017. Universitas PGRI Palembang.

Geminastiti., Kinanti., Nurlita., Nella. 2016. Ekonomi Untuk SMA /MA Kelas X. Bandung : Yrama Widya

Gunawan, Hendri. 2017. Implementasi Mata Kuliah Akuntansi Manajemen Sebagai Media Pembelajaran Keseharian Mahasiswa FKIP Akuntansi Universitas PGRI Palembang. Vol 01 Nomor 2 Jurnal Neraca PGRI Palembang

Harahap. Dahniar. 2016. Penggunaan Media Gambar Untuk Meningkatkan Hasil Belajar IPS Siswa. PGSD Univeritas Nahdlatul Ulama Sumatera Utara.

Hesty. Ria. Umri. 2018. Pengaruh Penerapan Media Flash Card Terhadap Hasil Belajar Siswa Pada Mata Pelajaran Ekonomi Di SMA Yayasan Bhakti 
Prabumulih Tahun Pelajaran 2017/2018. Universitas PGRI Palembang.

Jihad., Asep dan Haris., Abdul. 2013. Evaluasi Pembelajaran.

Yogyakarta : Multi Pressind

Parwati., Nyaman Ni., dkk. 2018.

Belajar dan Pembelajaran.

Depok : PT Rajagrafarindo

Persada

Sadiman., S., Arief., dkk. 2014.

Media Pendidikan Pengertian,

Pengembangan, dan

Pemanfaatan. Jakarta : PT

Rajagrafindo Persada

Sianipar, Bona, Muharrim. 2016.

Statistik Analisis Regresi \&

Korelasi. Palembang:

NoerFikri Palembang.

Sugiono. 2015. Metode Penelitian

Pendidikan Pendekatan

Kuantitatif, Kualitatif, dan

$R \& D$. Bandung : Alfabeta

Sugiono. 2017. Statistika Untuk

Penelitian. Bandung : Alfabeta

Suprijono., Agus. 2015.

Coomperative Learning Teori

dan Aplikasi Paikem.

Yogyakarta : Pustaka Pelajar 